\title{
Molecular Characterization of Pseudomonas syringae pv. coriandricola and Biochemical Changes Attributable to the Pathological Response on Its Hosts Carrot, Parsley, and Parsnip
}

\author{
Tatjana Popović, ${ }^{1, \dagger}$ Aleksandra Jelušić, ${ }^{2}$ Ivica Dimkić, ${ }^{3}$ Slaviša Stanković, ${ }^{3}$ Dobrivoj Poštić, ${ }^{1}$ Goran Aleksić, \\ and Sonja Veljović Jovanović \\ ${ }^{1}$ Institute for Plant Protection and Environment, Belgrade, Serbia \\ ${ }^{2}$ Institute for Multidisciplinary Research, University of Belgrade, Belgrade, Serbia \\ ${ }^{3}$ Faculty of Biology, University of Belgrade, Belgrade, Serbia
}

\begin{abstract}
Bacterial leaf spot caused by the plant pathogenic bacterium Pseudomonas syringae pv. coriandricola (Psc) was observed on carrot, parsnip, and parsley grown on a vegetable farm in the Vojvodina Province of Serbia. Nonfluorescent bacterial colonies were isolated from diseased leaves and characterized using different molecular techniques. Repetitive element PCR fingerprinting with five oligonucleotide primers (BOX, ERIC, $\mathrm{GTG}_{5}, \mathrm{REP}$, and SERE) and the randomly amplified polymorphic DNAPCR with the M13 primer revealed identical fingerprint patterns for all

tested strains. Multilocus sequence analysis of four housekeeping genes (gapA, gltA, gyrB, and $r p o D$ ) showed a high degree (99.8 to 100\%) of homology with sequences of Psc strains deposited in the PlantAssociated Microbes Database and NCBI database. The tested strains caused bacterial leaf spot symptoms on all three host plants. Hoststrain specificity was not found in cross-pathogenicity tests, but the plant response (peroxidase induction and chlorophyll bleaching) was more pronounced in carrot and parsley than in parsnip.
\end{abstract}

The large vegetable family Apiaceae (the parsley family) consists of 200 genera and $>2,900$ plant species grown worldwide, with representative members such as carrot (Daucus carota L.), parsley [Petroselinum crispum (Mill.) Fuss], parsnip (Pastinaca sativa L.), celery (Apium graveolens L.), fennel (Foeniculum vulgare Mill.), and coriander (Coriandrum sativum L.). Bacteria causing bacterial leaf spot were previously reported on the following: (i) coriander, reported from some European countries (Cazorla et al. 2005; Nemeth et al. 1969; Taylor and Dudley 1980; Toben and Rudolph 1996), North America (Bull and Koike 2012; Cerkauskas 2009; Cooksey et al. 1991; Pernezny et al. 1997), Australia (Dennis and Wilson 1997; Gooden et al. 1995; Refshauge and Nayudu 2001; Refshauge et al. 2010), and India (Gupta et al. 2013); (ii) parsley, reported from the United States (Bull and Koike 2012; Bull et al. 2011; Koike and Bull 2011; Xu and Miller 2013) and Turkey (Bozkurt et al. 2016); (iii) celery, reported from the United States (Bull and Koike 2012; Koike and Bishop 1990; Koike et al. 1994), and Greece (Elena et al. 2008); and (iv) fennel, reported from the United States (California; Jardini et al. 2012). Symptoms of the disease consist of brown-colored, angular-shaped, small leaf spots, limited by leaf veins and visible on both sides of the leaf. Each of these diseases was considered to be caused by different bacterial pathogens, and a study of the parsley pathogen based on multilocus sequence typing (MLST) revealed that bacterial spot disease might be caused by several pathovars that have a broader host range within the Apiaceae (Bull et al. 2011). Two Pseudomonas syringae pathovars have thus far been reported as causal agents of bacterial leaf spot and were identified as $P$. syringae pv. coriandricola $(P s c)$ and

${ }^{\dagger}$ Corresponding author: T. Popović; tanjaizbis@gmail.com

Funding: This work was supported by the Ministry of Education, Science and Technological Development, Republic of Serbia (projects nos. III43010 and OI173026).

The author(s) declare no conflict of interest.

Accepted for publication 24 June 2019.

(C) 2019 The American Phytopathological Society
P. syringae pv. apii (Psa) (Bull et al. 2011; Elena et al. 2008; Jardini et al. 2012; Koike et al. 1994; Toben and Rudolph 1996). These pathovars differ visually from each other in their ability to produce fluorescent pigment on King's B medium; that is, $P s c$ does not produce fluorescent pigment and Psa does (Bull et al. 2011; Gupta et al. 2013; Xu and Miller 2013). Clear separation between these two pathovars was also established using repetitive element PCR fingerprinting (rep-PCR) and MLST techniques, as previously described by Bull et al. (2011).

Some DNA profiling methods such as rep-PCR and use of randomly amplified polymorphic DNA (RAPD) have proved to be reliable techniques for the detection of genetic diversity among $P$. syringae pathovars (Gutiérrez-Barranquero et al. 2013; Louws et al. 1994). Owing to the wide distribution of these repetitive elements throughout the small genomes of prokaryotic organisms, rep-PCR is used as a fast and accurate typing technique capable of generating strain-specific fingerprints that can differentiate bacterial strains below the species or subspecies level (De Bruijn 1992; Little et al. 1998; Louws et al. 1994). Sarkar and Guttman (2004) confirmed that biochemical or physiological distinctions for reliable differentiation among $P$. syringae pathovars do not exist, and that a clearer picture can be obtained by using the MLST technique with four housekeeping genes: gapA (encoding glyceraldehyde-3phosphate dehydrogenase A), gltA (encoding citrate synthase), gyrB (encoding DNA gyrase B), and rpoD (encoding RNA polymerase sigma factor 70 ).

For the first time in Serbia, a severe bacterial leaf spot disease was observed on carrot, parsnip, and parsley under wet and cool conditions in the spring of 2014 , and the agent causing the disease was identified as Psc based on pathogenicity, biochemical tests, and sequencing data (Popović et al. 2015). Previously, only three host plant species (C. sativum, Levisticum officinale, and Ammi majus) had been described as susceptible to infection by Psc (Toben and Rudolph 1996). Our findings indicated that this pathovar has a broader host range within the family Apiaceae. In this study, Psc strains isolated from carrot, parsnip, and parsley in Serbia are characterized on the basis of genomic data (rep-PCR profiles and multilocus sequence analysis [MLSA]) to determine whether the populations from different hosts are homogenous and have the same origin. In addition, strain cross-pathogenicity in relation to some biochemical 
responses of the host is evaluated to test whether host-pathogen relatedness exists and to determine host susceptibility.

\section{Materials and Methods}

Bacterial strains and growth conditions. The $P s c$ strains used in this study (Table 1) were isolated from three different hosts of the family Apiaceae with expressed symptoms of leaf spot disease: carrot (coded as Pc25, Pc26, and Pc29), parsnip (coded as Pc50, Pc55, and Pc57), and parsley (coded as Pc70, Pc71, and Pc72) (Popović et al. 2015). The crops from which all strains originated were grown on the same vegetable farm, in the suburban settlement of Rimski Šančevi in Vojvodina, Serbia $\left(45.667754^{\circ} \mathrm{N}\right.$, $19.085809^{\circ} \mathrm{E}$ ), in 2014 . Strains were routinely grown in nutrient agar (NA) medium at $26^{\circ} \mathrm{C}$ and maintained as stock cultures stored at $-20^{\circ} \mathrm{C}$ in Luria Bertani broth (Difco) containing sterile glycerol (20\%, vol/vol).

Molecular characterization. Genomic DNA extraction. Genomic DNA from the tested $P s c$ strains was extracted using a modified version of the hexadecyltrimethyl ammonium bromide (CTAB) procedure of Le Marrec et al. (2000) described by Dimkić et al. (2013). All bacterial isolates were grown on NA medium for $48 \mathrm{~h}$ at $28^{\circ} \mathrm{C}$. A loopful of each pure bacterial culture was resuspended in sterile distilled water (SDW) and centrifuged at $10,000 \times g$ for $5 \mathrm{~min}$. The obtained pellet was resuspended in $567 \mu \mathrm{l}$ of TE buffer (10 mM of Tris, pH 8.0, and $1 \mathrm{mM}$ of EDTA) with the addition of $30 \mu \mathrm{l}$ of $10 \%$ sodium dodecyl sulfate and $3 \mu \mathrm{l}$ of proteinase $\mathrm{K}(20 \mathrm{mg} / \mathrm{ml}$ in $50 \%$ glycerol $)$. The mixture was incubated at $37^{\circ} \mathrm{C}$ for $30 \mathrm{~min}$. After the incubation period, $5 \mathrm{M}$ of $\mathrm{NaCl}$ was added, and DNA was purified by heating at $65^{\circ} \mathrm{C}$ for $10 \mathrm{~min}$ in $300 \mu \mathrm{l}$ of a solution of $3 \% \mathrm{CTAB}$ and polyvinylpyrrolidone. This step was followed by chloroform extraction one time and centrifugation at $10,000 \times g$ for $10 \mathrm{~min}$, where two phases were formed. A further step included the addition of one-tenth volume of $3 \mathrm{M}$ of Na-acetate (pH 5.0) and one volume of isopropanol, and $15 \mathrm{~min}$ of centrifugation at $10,000 \times \mathrm{g}$. The final phase consisted of pellet washing with $1 \mathrm{ml}$ of cold $96 \%$ ethanol and centrifugation at $10,000 \times g$ for $10 \mathrm{~min}$. The DNA obtained was resuspended in $50 \mu \mathrm{l}$ of TE buffer containing $1 \mu$ l of RNase $(10 \mathrm{mg} / \mathrm{ml})$ at a concentration of 20 to $30 \mathrm{ng}$ and stored at $-20^{\circ} \mathrm{C}$ before use.

Rep-PCR. Rep-PCR with BOX, ERIC and REP (Louws et al. 1994), GTG $_{5}$ (Versalovic et al. 1994), and SERE (Rajashekara et al. 1998) primers, as well as the RAPD-PCR with primer M13 (Huey and Hall 1989), was used to determine genetic polymorphism among the tested strains originating from carrot (Pc25, Pc26, Pc29), parsnip (Pc50, Pc55, Pc57), and parsley (Pc70, Pc71, Pc72). The primers used are listed in Table 2. Amplification of DNA bands was performed in a total volume of $25 \mu \mathrm{l}$ containing the following: $1 \mu \mathrm{l}$ of bacterial total DNA, $2.5 \mu \mathrm{l}$ of $10 \times$ KAPA Taq buffer, $0.5 \mu l$ of $10 \mathrm{mM}$ dNTP mixture (KAPA Biosystems), $2 \mu \mathrm{l}(10 \mu \mathrm{M})$ of primer sets (Table 1), $16.8 \mu \mathrm{l}$ of ultrapure DNase/RNase-free water (Gibco, Fisher Scientific), and $0.2 \mu \mathrm{l}(5 \mathrm{U} / \mu \mathrm{l})$ of KAPA Taq polymerase (KAPA Biosystems). The PCR amplifications were performed with a Mastercycler personal model (Eppendorf) using the following conditions: an initial denaturation cycle at $95^{\circ} \mathrm{C}$ for $7 \mathrm{~min}$ (BOX, ERIC, and REP PCR), $6 \mathrm{~min}\left(\mathrm{GTG}_{5} \mathrm{PCR}\right)$, or $5 \mathrm{~min}$ (SERE PCR) and at $94^{\circ} \mathrm{C}$ for $2 \mathrm{~min}$ (M13 PCR). This was followed by 30 cycles (BOX, ERIC, and $\mathrm{GTG}_{5}$ PCR), 35 cycles (REP and SERE PCR), or 40 cycles (M13 PCR) of denaturation at $94^{\circ} \mathrm{C}$ for $1 \mathrm{~min}$; primer annealing at $40^{\circ} \mathrm{C}\left(\mathrm{GTG}_{5}\right.$ and $\mathrm{REP}$ PCR), $50^{\circ} \mathrm{C}$ (SERE PCR), and $52^{\circ} \mathrm{C}$ (BOX and ERIC PCR) for

Table 1. List of Pseudomonas syringae pv. coriandricola strains used in this study and NCBI and Plant-Associated Microbes Database (PAMDB) accession numbers ${ }^{\mathrm{z}}$

\begin{tabular}{|c|c|c|c|c|c|c|}
\hline \multirow[b]{2}{*}{ Strain name } & \multirow[b]{2}{*}{ Host } & \multicolumn{4}{|c|}{ NCBI GenBank accession numbers } & \multirow[b]{2}{*}{ PAMDB } \\
\hline & & rpoD & gapA & gltA & gyrB & \\
\hline Pc25 & Daucus carota subsp. sativus (carrot) & - & - & - & - & - \\
\hline Pc26 & & KM979437 & MG198609 & MG198612 & KM979434 & 1807 \\
\hline Pc29 & & - & - & - & - & - \\
\hline Pc50 & Pastinaca sativa (parsnip) & - & - & - & - & - \\
\hline Pc55 & & KM979438 & MG198610 & MG198613 & KM979435 & 1808 \\
\hline Pc57 & & - & - & - & - & - \\
\hline Pc70 & Petroselinum crispum (parsley) & - & - & - & - & - \\
\hline Pc71 & & - & - & - & - & - \\
\hline Pc72 & & KM979439 & MG198611 & MG198614 & KM979436 & 1809 \\
\hline
\end{tabular}

${ }^{\mathrm{z}}$ Dashes indicate that sequences of certain strains are not deposited into the NCBI database, and thus the accession numbers are not provided.

Table 2. Primers used in repetitive element PCR fingerprinting profiling and multilocus sequence analysis

\begin{tabular}{lll}
\hline Primer/locus name & \multicolumn{1}{c}{ Primer sequence $\left(\mathbf{5}^{\prime}\right.$ to $\left.\mathbf{3}^{\prime}\right)$} & Reference \\
\hline BOXAIR & CTACGGCAAGGCGACGCTGACG & Louws et al. (1994) \\
ERIC1R & ATGTAAGCTCCTGGGGATTCAC & \\
ERIC2 & AAGTAAGTGACTGGGGTGAGCG & \\
REP1R-I & IIIICGICGICATCIGGC & Versalovic et al. (1994) \\
REP2-I & ICGICTTATCIGGCCTAC & Rajashekara et al. (1998) \\
GTG5 & GTGGTGGTGGTGGTG & Bonomo et al. (2008) \\
SERE & GTGAGTATATTAGCATCCGCA & Sarkar and Guttman (2004) \\
M13 & GAGGGTGGCGGTTCT & \\
gltA (For) & AGTTGATCATCGAGGGCGCWGCC & Hwang et al. (2005) \\
gltA (Rev) & TGATCGGTTTGATCTCGCACGG & \\
gapA (For) & CGCCATYCGCAACCCG & \\
gapA (Rev) & CCCAYTCGTTGTCGTACCA & \\
gyrB (For) & MGGCGGYAAGTTCGATGACAAYTC & \\
gyrB (Rev) & TRATBKCAGTCARACCTTCRCGSGC & \\
rpoD (For) & AAGGCGARATCGAAATCGCCAAGCG & \\
rpoD (Rev) & GGAACWKGCGCAGGAGTCGGCACG & \\
\hline
\end{tabular}

${ }^{\mathrm{z}}$ For $=$ forward and Rev $=$ reverse. 
1 min or $42^{\circ} \mathrm{C}$ for $20 \mathrm{~s}$ (M13 PCR); and polymerization at $65^{\circ} \mathrm{C}$ for $8 \mathrm{~min}$ (ERIC, $\mathrm{GTG}_{5}$, and REP PCR) and at $72^{\circ} \mathrm{C}$ for $8 \mathrm{~min}(\mathrm{BOX}$ PCR) and 2 min (SERE and M13 PCR). The final extension step was performed at $65^{\circ} \mathrm{C}$ (ERIC, $\mathrm{GTG}_{5}$, and REP PCR) and at $72^{\circ} \mathrm{C}$ (BOX and SERE PCR) for $16 \mathrm{~min}$, or at $72^{\circ} \mathrm{C}$ for $10 \mathrm{~min}$ (M13 PCR). The generated fingerprints were visualized using gel electrophoresis on $1 \%$ agarose gels in $0.5 \times$ TBE buffer stained with ethidium bromide for $2 \mathrm{~h}$ at $90 \mathrm{~V}$. For visualization, PCR products were mixed with DNA Gel Loading Dye $6 \times$ (Thermo Scientific) and visually compared.

MLSA. MLSA was performed using partial coding sequences of four housekeeping genes: gapA, gyrB and $r p o D$ (Hwang et al. 2005), and gltA (Sarkar and Guttman 2004) (Table 2). The PCR mixture $(25 \mu \mathrm{l})$ was composed of $12.5 \mu \mathrm{l}$ of KAPA Taq ReadyMix (a doubly concentrated solution of Taq DNA polymerase in $0.05 \mathrm{U} / \mu \mathrm{l}$ of reaction buffer with a $0.4 \mathrm{mM}$ concentration of each dNTP; Kapa Biosystems), $1 \mu \mathrm{l}$ of the primers $(10 \mu \mathrm{M})$ in each primer set, $9.5 \mu \mathrm{l}$ of ultrapure DNases/RNase-free water, and $1 \mu \mathrm{l}$ of target DNA. All PCR amplifications were performed according to Sarkar and Guttman (2004) with an initial denaturation at $94^{\circ} \mathrm{C}$ for $3 \mathrm{~min}$, followed by 30 cycles of denaturation at $94^{\circ} \mathrm{C}$ for $2 \mathrm{~min}$; annealing at $54^{\circ} \mathrm{C}($ gapA $), 56^{\circ} \mathrm{C}($ gltA $), 62^{\circ} \mathrm{C}$ $($ gyrB $)$, or $63^{\circ} \mathrm{C}(r p o D)$ for $1 \mathrm{~min}$; extension at $72^{\circ} \mathrm{C}$ for $1 \mathrm{~min}$; and a subsequent final extension step at $72^{\circ} \mathrm{C}$ for $10 \mathrm{~min}$. The obtained PCR products were checked for the presence of a band of expected size in relation to $1 \mathrm{~kb}$ on the GeneRuler DNA Ladder (Thermo Scientific) using electrophoresis. The products were then purified using the QIAquick PCR Purification and Gel Extraction Kits (QIAGEN GmbH, Hilden, Germany) and sent for sequencing to the Macrogen Sequencing Service in the Netherlands. The sequences generated after PCR amplification were deposited in the NCBI GenBank database and Plant-Associated Microbes
Database (PAMDB) and their accession numbers are shown in Table 1 .

Phylogenetic analysis. The sequences obtained from the Macrogen Sequencing Service were checked for quality, aligned using CLUSTAL W implemented in the BioEdit program (version 7.1.3), and searched for homology with sequences deposited in the PAMDB (http://genome.ppws.vt.edu/blast_MLST/blast.html) and NCBI (https://blast.ncbi.nlm.nih.gov/Blast.cgi) databases. Using the data available in these databases, two phylogenetic trees were made to compare the tested strains with already deposited PSC strains and with 20 and four sequences of strains of other $P$. syringae pathovars from PAMDB and NCBI, respectively (Tables 3 and 4).

When PAMDB data were used, all of our sequences were trimmed to the following nucleotide sizes: gapA (476 nt), $g y r B$ $(507 \mathrm{nt})$, and $\operatorname{rpoD}(381 \mathrm{nt})$. In addition, individual alignments were performed and concatenated sequences in a total length of 1,364 nt were made and used for phylogenetic analysis. A phylogenetic tree was constructed using the neighbor-joining algorithm. The tree was constructed using Mega 7.0 software, and genetic distances were computed using the Kimura two-parameter nucleotide substitution model (Kimura 1980; Kumar et al. 2016). The tree was rooted with the sequence of an outgroup strain, $P$. viridiflava BS0001.

When NCBI data were used, our sequences were aligned and trimmed to exact sizes with those from the NCBI database (gapA, $476 \mathrm{nt}$; gltA, $310 \mathrm{nt}$; gyrB, $455 \mathrm{nt}$; and $r p o D, 385 \mathrm{nt}$ ) and concatenated sequences were made $(1,626 \mathrm{nt})$. A phylogenetic tree was constructed according to the same procedure as described above. The sequence of $P$. viridiflava strain CFBP 1590 was used as an outgroup sequence.

Pathogenicity assay. For the pathogenicity assay, plants of carrot, parsnip, and parsley were raised from seeds sown in plastic

Table 3. $P$. syringae pathovar strains from the Plant-Associated Microbes Database (PAMDB) used for multilocus sequence analysis with strains used in this study ${ }^{\mathrm{z}}$

\begin{tabular}{|c|c|c|c|c|c|}
\hline Species & Strain number & Host & Year & Country & $\begin{array}{c}\text { PAMDB accession } \\
\text { number }\end{array}$ \\
\hline P. s. pv. coriandricola & BS456 & Petroselinum crispum (parsley) & 2003 & Salinas, California (U.S.) & 783 \\
\hline P. s. pv. coriandricola & BS462 & Petroselinum crispum (parsley) & 2002 & Salinas, California (U.S.) & 784 \\
\hline P. s. pv. coriandricola & BS821 & Petroselinum crispum (parsley) & 2005 & Yuma, Arizona (U.S.) & 786 \\
\hline P. s. pv. coriandricola & BS2059 & - & 2006 & Santa Maria, California (U.S.) & 787 \\
\hline P. s. pv. coriandricola & BS2091 & Petroselinum crispum (parsley) & 2006 & Turlock, California (U.S.) & 788 \\
\hline P. s. pv. coriandricola & BS2097 & Petroselinum crispum (parsley) & 2006 & Turlock, California (U.S.) & 789 \\
\hline P. s. pv. coriandricola & BS2705 & Petroselinum crispum (parsley) & 2009 & King City, California (U.S.) & 792 \\
\hline P. s. pv. coriandricola $^{\mathrm{pt}}$ & BS2673 (ICMP 12471) & - & - & - & 795 \\
\hline P. s. pv. coriandricola ${ }^{\mathrm{pt}}$ & BS2888 & - & - & - & 880 \\
\hline P. s. pv. coriandricola & SM69-07 & Petroselinum crispum (parsley) & 2007 & Ohio (U.S.) & 1138 \\
\hline$P$ s. pv. syringae ${ }^{\mathrm{pt}}$ & BS2733 (LMG 1247) & - & - & - & 796 \\
\hline P. s. pv. syringae & 61 & Phaseolus vulgaris (bean) & - & - & 67 \\
\hline P. s. pv. syringae & B76 & Lycopersicon esculentum (tomato) & - & Georgia (U.S.) & 73 \\
\hline P. s. pv. syringae & $1212 \mathrm{R}$ & Pisum sativum (pea) & - & - & 68 \\
\hline P. s. pv. pisi $i^{\mathrm{pt}}$ & BS2753 (NCPPB 2585) & - & - & - & 815 \\
\hline P. s. pv. pisi & H6E5 & Pisum sativum (pea) & 1994 & & 59 \\
\hline$P . s . \mathrm{pv} . a i i^{\mathrm{pt}}$ & BS2889 (NCPPB 1626) & Apium graveolens var. dulce (celery) & 1942 & U.S. & 908 \\
\hline P. s. pv. aptata & 601 & Beta vulgaris (sugarbeet) & 1966 & - & 94 \\
\hline P. s. pv. aptata $^{\mathrm{pt}}$ & BS291 (CFBP 1617) & - & - & - & 776 \\
\hline P. s. pv. atrofaciens & DSM5025 & Triticum aestivum (wheat) & - & - & 3 \\
\hline P. s. pv. atrofaciens $\mathrm{pt}^{\mathrm{t}}$ & BS2457 (LMG 5095) & - & - & - & 794 \\
\hline P. s. pv. glycinea ${ }^{\mathrm{pt}}$ & BS2748 (LMG 5066) & - & - & - & 810 \\
\hline P. s. pv. glycinea & LN10 & Glycine max (soybean) & 1994 & & 15 \\
\hline P. s. pv. phaseolicola $\mathrm{pt}^{\mathrm{pt}}$ & BS2739 (LMG 2245) & - & - & - & 801 \\
\hline P.s. pv. phaseolicola & HB10Y & Phaseolus vulgaris (bean) & - & - & 49 \\
\hline P. s. pv. lachrymans & 107 & Cucumis sativus (cucumber) & - & - & 21 \\
\hline P. s. pv. tabaci $\mathrm{pt}^{\mathrm{pt}}$ & BS2917 (NCPPB 1427) & - & - & - & 890 \\
\hline P. s. pv. tabaci & LMG5393 & Nicotiana tabacum (tobacco) & 1959 & Hungary & 879 \\
\hline P. s. pv. tomato ${ }^{\mathrm{pt}}$ & BS287 (CFBP 2212) & - & - & - & 882 \\
\hline P. s. pv. helianthi $i^{\mathrm{pt}}$ & LMG 5067 & - & - & - & 811 \\
\hline$P$. viridiflava & BS0001 & Actinidia deliciosa (kiwifruit) & 2008 & Brescia, Lombardy (Italy) & 1140 \\
\hline
\end{tabular}

${ }^{\mathrm{z}}$ The superscript pt indicates pathotype strain for certain species. Dashes indicate that information for a given item does not exist. 
pots filled with a fertilized substrate (Domoflor Mix 6; Domoflor UAB, Vilnius, Lithuania). Pots were placed in a growth chamber under controlled conditions of $30^{\circ} \mathrm{C} / 20^{\circ} \mathrm{C}$ (day/night) temperature, a 16-h daylight regime, light intensity of 2,700 to 3,000 lx, and 30 to $40 \% \mathrm{RH}$. Plants were inoculated 5 weeks after sowing, in the three to five true leaf stage (BBCH 13-15), using a method involving spraying inocula onto leaf surfaces until runoff occurred. Bacterial inocula were prepared from strains grown on nutrient sucrose agar (NSA) at $27^{\circ} \mathrm{C}$ for $24 \mathrm{~h}$ and suspended in $250 \mathrm{ml}$ of SDW to a concentration of approximately $10^{8} \mathrm{CFU} /$ $\mathrm{ml}$. The plants were kept in a highly humid condition $(100 \%$ $\mathrm{RH})$ for $6 \mathrm{~h}$ before and $48 \mathrm{~h}$ after the inoculation. After that, they were kept at a temperature of $22 \pm 2{ }^{\circ} \mathrm{C}$ and $\mathrm{RH}$ of 70 to $80 \%$. Five plants of each host were tested for each of the nine representative $P s c$ isolates. The experiment was performed in four replications. Plants treated with SDW served as a negative control. The plants were observed daily for symptom formation over a period of 3 weeks. Pathogenicity was checked in two independent experiments (each in four replicates).

Plants were checked visually for the presence of bacterial spot symptoms 21 days after inoculation using the Horsfall-Barratt rating scale (Horsfall and Barratt 1945), which was originally designed to compensate for error in interpretation of the percentage of infected foliage and converted to a percentage using so-called Elanco tables (Redman et al. 1969) (Table 5). Numerical values were given for the percentage of leaf area showing disease symptoms and then converted using midpoint percentages prior to statistical analyses.

The analysis of variance was supported by the KolmogorovSmirnov test for the normality of residuals. The obtained data were subjected to one-way analysis of variance, and separation of means of the percentage of infection in planta was accomplished using Tukey's honest significant difference test. Results were considered significant at $P<0.05$. Statistical analyses were conducted using the general procedures of STATISTICA version 7 (StatSoft Inc.) and IBM SPSS Statistics version 20 (SPSS Inc.).

Reisolations were performed from leaves of each host showing bacterial leaf spot symptoms. One bacterial reisolate from each inoculated host was taken to confirm its being identical to the original isolates using so-called LOPAT biochemical tests (Lelliott and Stead 1987; Schaad et al. 2001) and M13 PCR fingerprinting.
Biochemical changes in inoculated hosts. Peroxidase extraction and electrophoresis. Symptomatic and asymptomatic fresh leaves of carrot, parsley, and parsnip previously inoculated with the tested strains (Pc26, Pc55, Pc72) or SDW (negative control) were frozen in liquid nitrogen, powdered in a mortar, and extracted in $100 \mathrm{mM}$ of sodium phosphate buffer ( $\mathrm{pH} 6.5$ ) with $2 \mathrm{mM}$ of phenylmethylsulphonyl fluoride. The homogenate was centrifuged at $10,000 \times g$ for $10 \mathrm{~min}$ at $4^{\circ} \mathrm{C}$, and the supernatant was used for measurement of class III peroxidase (POD) (E.C.1.11.1.7) activity and separation of POD isoforms. POD activity of the soluble protein fraction was measured spectrophotometrically with guaiacol as a substrate at $25^{\circ} \mathrm{C}$ using a Shimadzu UV-160 temperature-controlled spectrophotometer (Shimadzu, Kyoto, Japan). The reaction mixture consisted of $100 \mathrm{mM}$ of Na-phosphate buffer (pH 6.5), 0.01 $\mathrm{M}$ of guaiacol, and a 20- $\mu$ l aliquot of a sample. The reaction was started by adding $\mathrm{H}_{2} \mathrm{O}_{2}$ to $10 \mathrm{mM}$, and the increase in absorbance at $470 \mathrm{~nm}$ was then followed. POD activity was calculated using the extinction coefficient for guaiacol oxidation products (26.6 $\mathrm{mM}^{-1}$ ) (Kukavica and Jovanović 2004).

Isoelectrofocusing of soluble POD from leaf extracts was carried out in a $7.5 \%(\mathrm{wt} / \mathrm{vol})$ polyacrylamide gel with $3 \mathrm{M}$ of urea and $2 \%$ ampholyte (Serva, Heidelberg, Germany) at $4^{\circ} \mathrm{C}$ for $3 \mathrm{~h}$. Isoelectrofocusing was performed at a gradually increasing voltage: $90 \mathrm{~min}$

Table 5. Horsfall-Barratt scale used to estimate the severity of bacterial leaf spot disease ${ }^{\mathrm{z}}$

\begin{tabular}{lccc}
\hline Rating & $\begin{array}{c}\text { Infected leaf } \\
\text { area }(\%)\end{array}$ & Range & $\begin{array}{c}\text { Midpoint } \\
\text { (Elanco formula) }\end{array}$ \\
\hline 0 & 0 & 0 & 0 \\
1 & $>0$ to 3 & 3 & 1.5 \\
2 & $>3$ to 6 & 3 & 4.5 \\
3 & $>6$ to 12 & 6 & 9.0 \\
4 & $>12$ to 25 & 13 & 18.5 \\
5 & $>25$ to 50 & 25 & 37.5 \\
6 & $>50$ to 75 & 25 & 62.5 \\
7 & $>75$ to 87 & 12 & 81.5 \\
8 & $>87$ to 94 & 7 & 91 \\
9 & $>94$ to 97 & 3 & 96.5 \\
10 & $>97$ to 100 & 3 & 98.5 \\
11 & 100 & 0 & 100 \\
\hline
\end{tabular}

${ }^{\mathrm{z}}$ See Horsfall and Barratt (1945) and Redman et al. (1969).

Table 4. P. syringae pathovar strains from the NCBI database used for multilocus sequence analysis with strains used in this study

\begin{tabular}{|c|c|c|c|c|c|c|c|}
\hline \multirow[b]{2}{*}{ Species } & \multirow{2}{*}{$\begin{array}{c}\text { Strain } \\
\text { number }\end{array}$} & \multirow[b]{2}{*}{ Host } & \multirow[b]{2}{*}{ Country } & \multicolumn{4}{|c|}{ NCBI database accession number } \\
\hline & & & & gapA & gltA & $\operatorname{gyr} B$ & $r p o D$ \\
\hline $\begin{array}{l}\text { P. s. pv. } \\
\text { coriandricola }\end{array}$ & SUPP3309 & Coriandrum sativum (coriander) & Shizuoka (Japan) & LC312432 & LC321982 & LC310752 & LC312425 \\
\hline $\begin{array}{l}\text { P. s. pv. } \\
\text { coriandricola }\end{array}$ & SUPP3326 & C. sativum (coriander) & Shizuoka (Japan) & LC312428 & LC321978 & LC311058 & LC312421 \\
\hline $\begin{array}{l}\text { P. s. pv. } \\
\text { coriandricola }\end{array}$ & SUPP3327 & C. sativum (coriander) & Shizuoka (Japan) & LC312429 & LC321979 & LC311059 & LC312422 \\
\hline $\begin{array}{l}\text { P. s. pv. } \\
\text { coriandricola }\end{array}$ & SUPP3328 & C. sativum (coriander) & Shizuoka (Japan) & LC312430 & LC321981 & LC311060 & LC312423 \\
\hline $\begin{array}{l}\text { P. s. pv. } \\
\text { coriandricola }\end{array}$ & SUPP3330 & C. sativum (coriander) & Shizuoka (Japan) & LC312431 & LC321980 & LC311061 & LC312424 \\
\hline $\begin{array}{l}\text { P. s. pv. } \\
\text { coriandricola }\end{array}$ & SUPP3344 & C. sativum (coriander) & Chiba (Japan) & LC312433 & LC321983 & LC311062 & LC312426 \\
\hline $\begin{array}{l}\text { P. s. pv. } \\
\text { coriandricola }\end{array}$ & SUPP3345 & C. sativum (coriander) & Chiba (Japan) & LC312434 & LC321984 & LC311063 & LC312427 \\
\hline P. s. pv. tomato & CFBP2212 ${ }^{\mathrm{T}}$ & Lycopersicon esculentum (tomato) & U.K. & KF937402 & KF937499 & KF937596 & KF937693 \\
\hline $\begin{array}{l}\text { P. s. pv. } \\
\text { maculicola }\end{array}$ & $5309-1$ & Brassica napus (oilseed rape) & Canada & KJ641615 & KJ634662 & KJ634656 & KJ634659 \\
\hline P. s. pv. syringae & LMG $1247^{\mathrm{T}}$ & Syringa vulgaris (lilac) & U.K. & HG000210 & HG000145 & HG000275 & HG000080 \\
\hline P. s. pv. syringae & B728a & Phaseolus vulgaris (snap bean) & Wisconsin (U.S.) & NC_007005 & NC_007005 & NC_007005 & NC_007005 \\
\hline P. s. pv. syringae & LMG 1247 & S. vulgaris (lilac) & U.K. & HG000210 & HG000145 & HG000275 & HG000080 \\
\hline P. s. pv. pisi & ATCC 11043 & Pisum sativum (peas) & U.S. & KP211403 & KP211407 & KP211405 & KP211409 \\
\hline $\begin{array}{l}\text { P. s. pv. } \\
\text { atrofaciens }\end{array}$ & LMG5095 & Triticum aestivum (wheat) & New Zealand & NZ_CP028490 & NZ_CP028490 & NZ_CP028490 & NZ_CP028490 \\
\hline P. viridiflava & CFBP 1590 & Prunus cerasus (cherry) & France & LT855380 & LT855380 & LT855380 & LT855380 \\
\hline
\end{tabular}


at $100 \mathrm{~V}, 60 \mathrm{~min}$ at $250 \mathrm{~V}$, and $30 \mathrm{~min}$ at $500 \mathrm{~V}$. The anode buffer was $10 \mathrm{mM}$ of phosphoric acid and the cathode buffer was $20 \mathrm{mM}$ of $\mathrm{NaOH}$ with $3 \%$ ampholyte on a pH gradient of 3 to 9 (Kukavica et al. 2012). To detect POD activity after electrophoresis, the gel was incubated with $10 \%$ 4-chloro- $\alpha$-naphthol and $0.03 \% \mathrm{H}_{2} \mathrm{O}_{2}$ in $100 \mathrm{mM}$ of sodium phosphate buffer (pH 6.5) (Kukavica et al. 2012).

Chlorophyll and flavonoid measurements. Total chlorophyll content and content of leaf epidermal flavonoids (EpFlav, DA ${ }_{375}$ ) were measured in vivo with a Dualex FLAV(FORCE-A) apparatus (Orsay, France) (Cerović et al. 2012). Measurements were taken from 7 to 10 leaves per repetition on days 3, 12, and 20 after inoculation (Cerović et al. 2012).

\section{Results}

Molecular characterization. The results of rep- and RAPDPCR fingerprinting analysis for all six primer pairs used (BOX,
M13 PCR

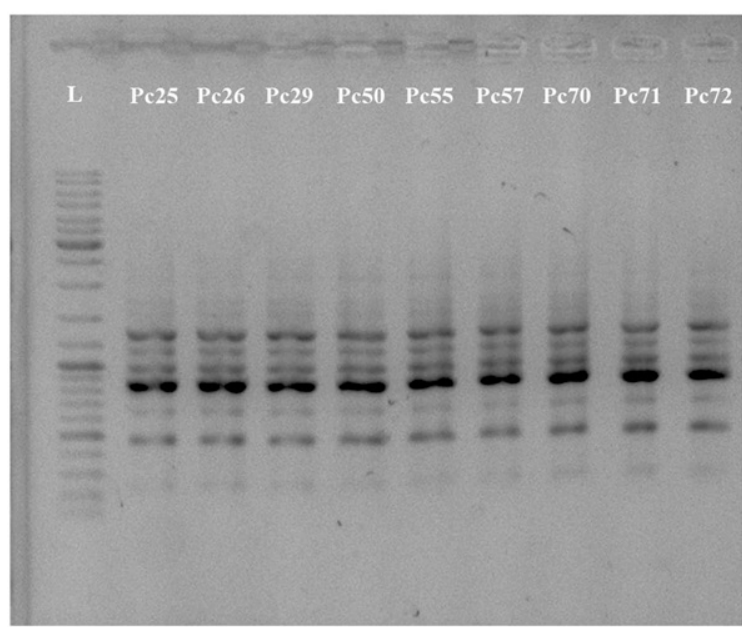

ERIC PCR

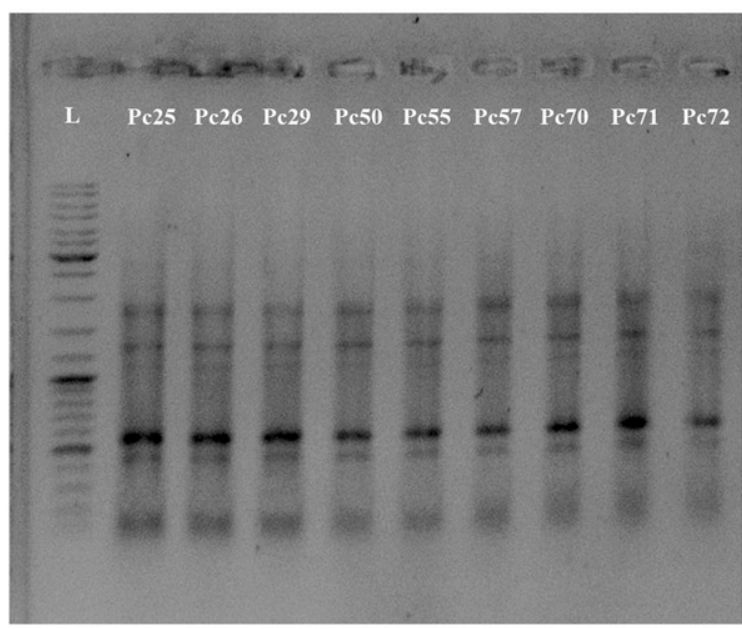

SERE PCR

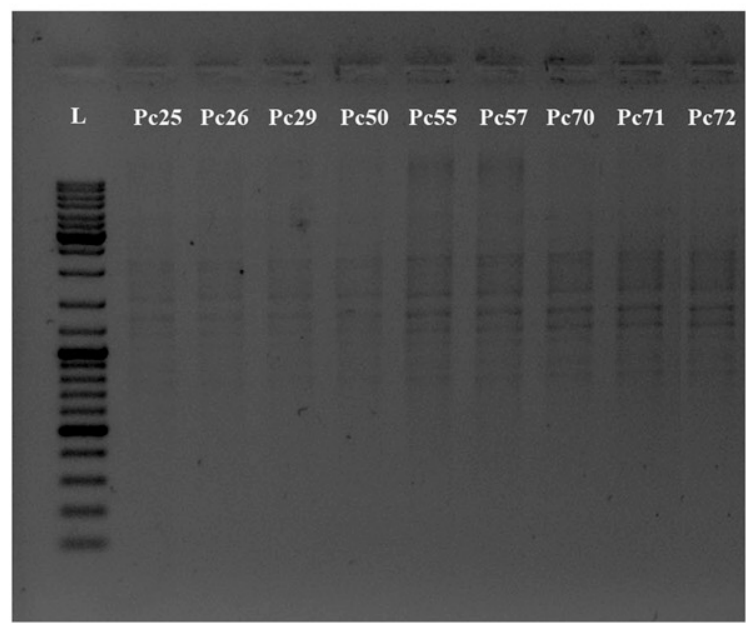

REP PCR

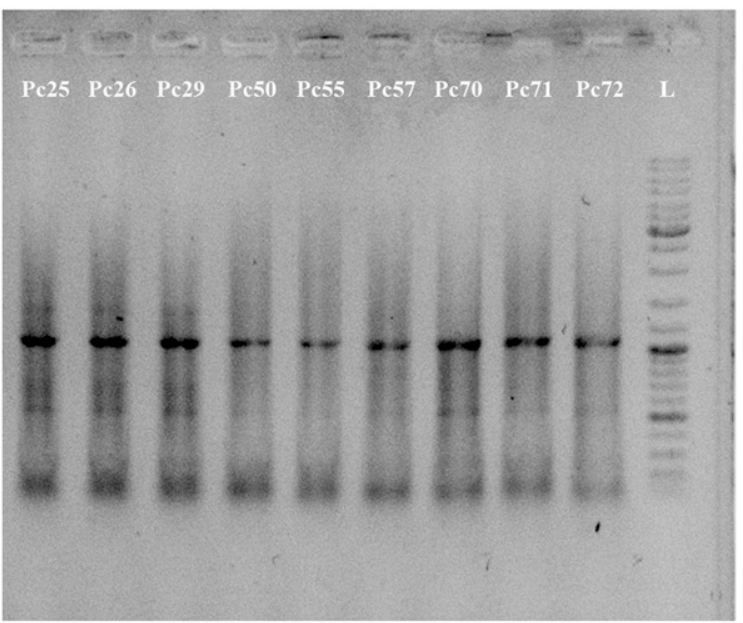

GTG PCR

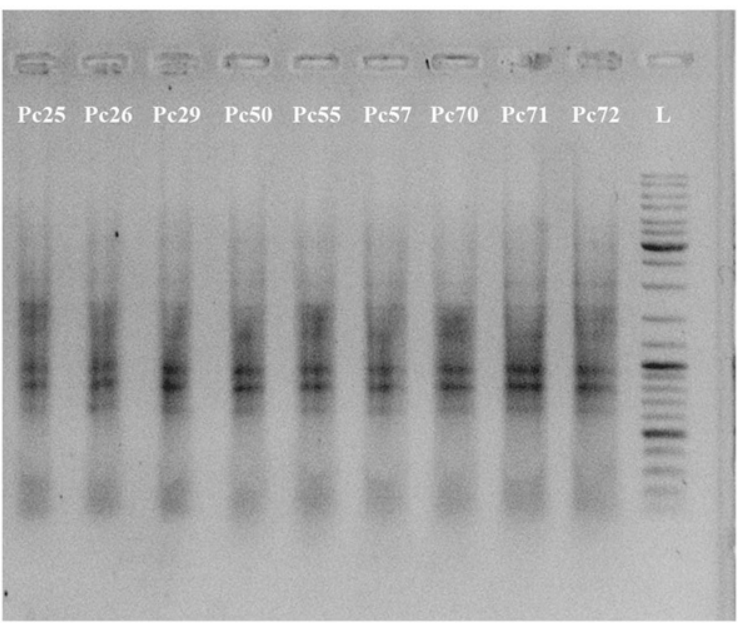

BOX PCR

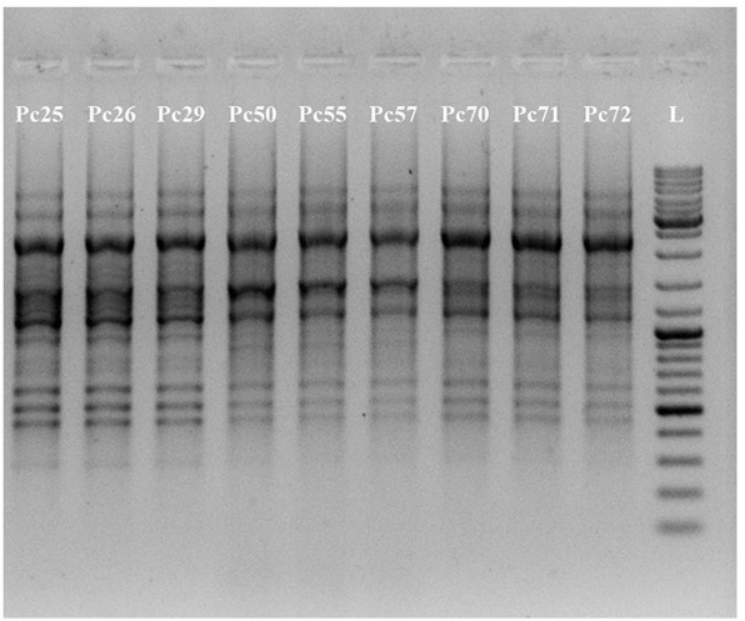

Fig. 1. Results of randomly amplified polymorphic DNA and repetitive element PCR fingerprinting using six primers for each of the tested Pseudomonas syringae pv. coriandricola strains, originating from carrot (Pc25, Pc26, Pc29), parsnip (Pc50, Pc55, Pc57), or parsley (Pc70, Pc71, Pc72). L = 1-kb GeneRuler DNA ladder. 
ERIC, GTG 5 , REP, SERE, M13) are shown in Figure 1. The DNA profiles were visually identical using all of the tested primers, revealing high genetic homogeneity between the tested Psc strains isolated from carrot, parsnip, and parsley in Serbia. It turned out that BOX, SERE, and M13 PCR fingerprinting techniques generated the most complex banding patterns, with an average of 12,8 , and 10 bands, respectively, and with amplification size between 400 and $4,000 \mathrm{bp}$.
In PAMDB, BLAST analysis of the gapA and $g y r B$ sequences showed 100\% homology among all Psc strains (BS456, BS426, BS821, BS2059, BS2091, BS2097, 2075, ICMP 12471, BS2888, and SM69-07), whereas the rpoD gene showed 99\% homology with the sequence of $P S C$ pathotype strains ICMP 12471 and BS2888, as well as with that of strain SM69-07. Sequencing of the gltA gene determined the strains only to the species level $(P$. syringae) with $96 \%$ homology, indicating higher discriminatory

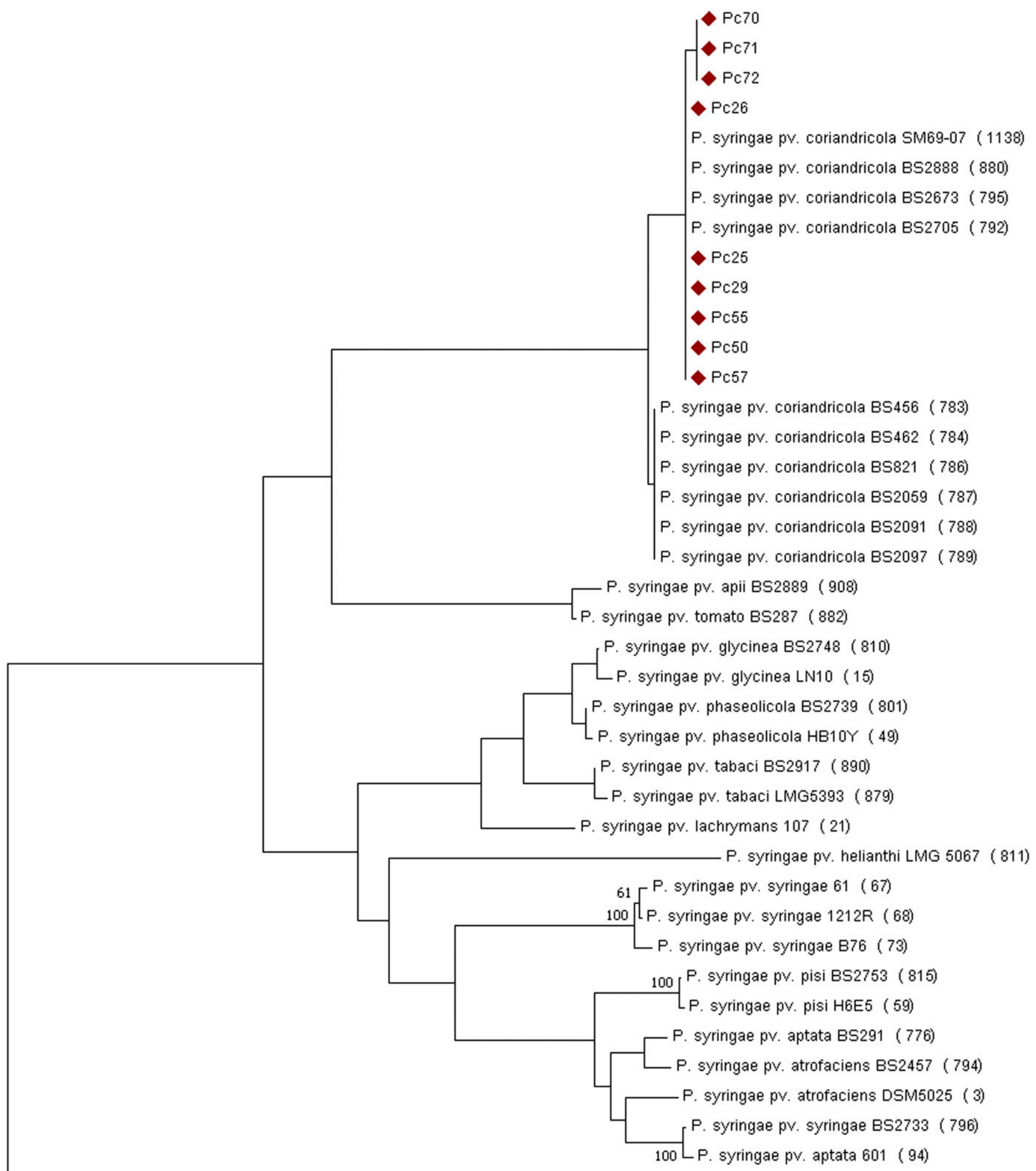

P. viridiflava BS0001 (1140)

Fig. 2. Neighbor-joining phylogenetic tree based on the concatenated sequences of gapA, gyrB, and rpoD from tested Pseudomonas syringae pv. coriandricola strains and selected P. syringae pathovars deposited in the Plant-Associated Microbes Database. The tree was rooted with $P$. viridiflava BS0001 as an outgroup strain. 
ability of the gapA, gyrB, and $r p o D$ genes. A neighbor-joining phylogenetic tree constructed with concatenated sequences of the tested Psc strains and those of strains from PAMDB (Table 3) showed two closely related phylogenetic groups of $P s c$, one with all nine tested strains originating from carrot, parsley, and parsnip, two pathotype strains (BS2673 and BS2888), and two additional strains (SM69-07 and BS2705) from parsley (Fig. 2). The second group consisted of the remaining Psc strains from curled-leaf (BS456), flat-leaf (BS462, BS821, BS2097), and double-curled (BS2091) parsley and strain BS2059 (origin not defined) used for comparison. Two P. syringae pathovars, apii (BS2889) and tomato (BS287), were phylogenetically more closely related to $P s c$ strains than the other nine P. syringae pathovars (aptata, atrofaciens, glycinea, helianthi, lachrymans, pisi, phaseolicola, syringae, and tabaci), which were grouped in the second phylogenetic tree cluster.

In the NCBI database, the tested Psc strains from Serbia on all four loci (gapA, gltA, gyrB, and rpoD) showed 100\% homology with Psc strains SUPP3309, SUPP3326-3328, SUPP3330, SUPP3344, and SUPP3345. A concatenated neighbor-joining phylogenetic tree with the tested Psc strains and strains from other pathovars (atrofaciens, maculicola, syringae, pisi, and tomato) retrieved from the NCBI database (Table 4) grouped all Psc strains together (Fig. 3). Other $P$. syringae pathovars were grouped in separate tree clusters, one with $P$. syringae pv. tomato (CFBP2212) and maculicola (5309-1) type strains, which were phylogenetically more closely related to Psc strains, and the second cluster with two Psc strains (B728a and LMG $1247^{\mathrm{T}}$ ) and pathovars atrofaciens (LMG5095) and pisi (ATCC 11043), showing their relatedness. The outgroup strain $P$. viridiflava (CFBP 1590) was situated on an isolated tree branch.
Pathogenicity assay. All nine of the tested strains of Psc caused symptoms in the guise of leaf spots on all three host plant species. Symptoms started appearing 8 days after inoculation as small water-soaked spots on the inoculated leaves. Leaf symptoms similar to those on the original plants were observed for 21 days after inoculation, during which the plants were rated. Disease intensity differed, not between strains, but rather between hosts (Fig. 4). Parsley and carrot were more susceptible, with disease intensity ranging from 24.3 to $34.5 \%$ and from 22.9 to $32.6 \%$, respectively (Figs. 4 and 5), whereas that of parsnip was from 1.7 to $2.9 \%$. Symptoms did not develop on the negative control plants treated with SDW.

Nine nonfluorescing bacterial reisolates obtained from each of the inoculated hosts were confirmed to be identical to the original isolates using the LOPAT tests, where reactions corresponded to LOPAT group Ia (+-+). Results of M13 PCR fingerprinting revealed the same banding patterns as the original ones. Target bacteria were not isolated from the negative control plants.

Biochemical changes in inoculated hosts. Chlorophyll content decreased by about $35 \%$ in carrot plants inoculated with strains Pc26 (carrot) and Pc72 (parsley), whereas chlorosis was not developed when plants were inoculated with strain Pc55 (parsnip) (Table 6). On the other hand, in diseased parsley and parsnip plants, chlorophyll content did not change significantly compared with the negative control plants throughout the whole experiment.

Induction of phenolic biosynthesis is another indicator of abiotic and biotic stresses in plants. We measured the accumulation of leaf epidermal flavonoids with the aim of using it as an indicator of the activation of phenolic metabolism. Compared with parsnip, leaves

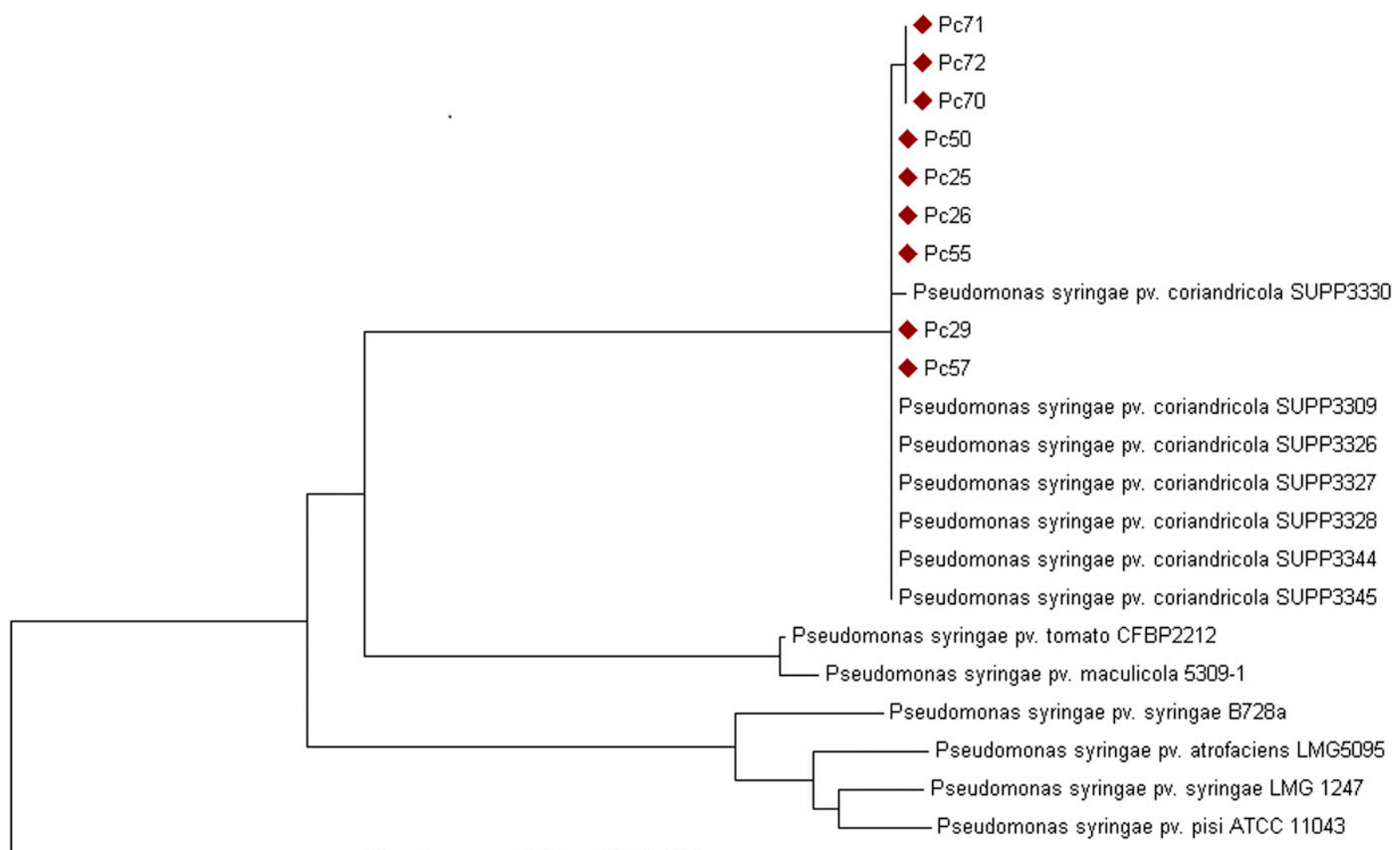

Pseudomonas viridiflava CFBP 1590

$$
0.01
$$

Fig. 3. Neighbor-joining phylogenetic tree based on the concatenated sequences of gapA, gltA, gyrB, and rpoD from tested Pseudomonas syringae pv. coriandricola strains and the closest $P$. syringae pathovars deposited in the NCBI database. The tree was rooted with $P$. viridiflava CFBP 1590 as an outgroup strain. 
of carrot and parsley accumulated greater amounts of epidermal flavonoids, the levels of which decreased by $50 \%$ on days 3 and 12 in diseased carrot and parsley, respectively. Parsley leaves recovered flavonoids in the epidermis 3 weeks after inoculation, but only in those plants inoculated with Pc26 (carrot) and Pc72 (parsley). Similar changes were observed in parsnip. The level of total class III POD activity in symptomatic and asymptomatic carrot leaves infected with $P s c$ strain Pc26 isolated from carrot, measured 20 days after inoculation, increased by $30 \%$. In the other two plant species (parsley and parsnip), POD activity did not change significantly in asymptomatic leaves, whereas it doubled in parsnip and parsley leaves where visible symptom (spots) were present (Fig. 6). In all cases, no new inducible isoforms were found (data not shown).

\section{Discussion}

$P$. syringae is a phytopathogenic bacterium responsible for a variety of bacterial spot, speck, and blight symptoms with a very large host range (Sarkar and Guttman 2004). Because of the heterogeneous nature of this species, it is hard to determine $P$. syringae pathovars relying only on classical methods of determination based on phenotypic and biochemical characterization. This study is an upgrade and continuation of earlier research that complements the first report of $P s c$ on carrot, parsley, and parsnip in Serbia, where this pathovar was identified based on colony morphology, biochemical tests, and pathogenicity (Popović et al. 2015). For better insight into genetic features of bacterial species, many molecular techniques, such as DNA-DNA hybridization and
MLSA of housekeeping genes (Bull et al. 2011; Chapman et al. 2012; Gardan et al. 1999), have been proposed. Highly conservative DNA elements BOX, ERIC, REP, GTG $_{5}$, and SERE are ubiquitous and widely distributed through the genome of many plant pathogenic bacteria and therefore can be used as reliable tools for rapid and simple fingerprint comparison, especially where differentiation based on phenotypic features does not give enough information (De Bruijn 1992; Louws et al. 1994). All six PCR fingerprinting primers used in this study showed identical DNA banding patterns, demonstrating high genetic homogeneity among the tested $P s c$ strains regardless of host affiliation. It turned out that BOX, SERE, and M13 PCR generated the most complex and visually most receptive patterns. Thus, BOX, SERE, or M13 PCR primers are the best primers for fast screening of $P s c$ strains and can be recommended for future genetic analysis of $P s c$. The BOX and ERIC oligonucleotide primers generated DNA fingerprinting patterns identical to those obtained in a study of typing of $P s c$ strains isolated from parsley (Bull et al. 2011). Significant results in separation of $P$. syringae into genomospecies were previously confirmed using the BOXA1R rep-PCR fingerprinting primer (Marques et al. 2000). Division of $P$. syringae species into nine genomospecies was also confirmed based on DNA-DNA hybridization (Gardan et al. 1999).

In many earlier studies, rep-PCR was successfully used together with MLSA for typing of different $P$. syringae pathovars (Bull et al. 2011; Marques et al. 2008; Morris et al. 2000). In our study, the four housekeeping genes $r p o D$, gapA, gltA, and gyrB proved to be reliable tools for pathovar identification, since all tested strains

\section{口Carrot 요 Parsley DParsnip}

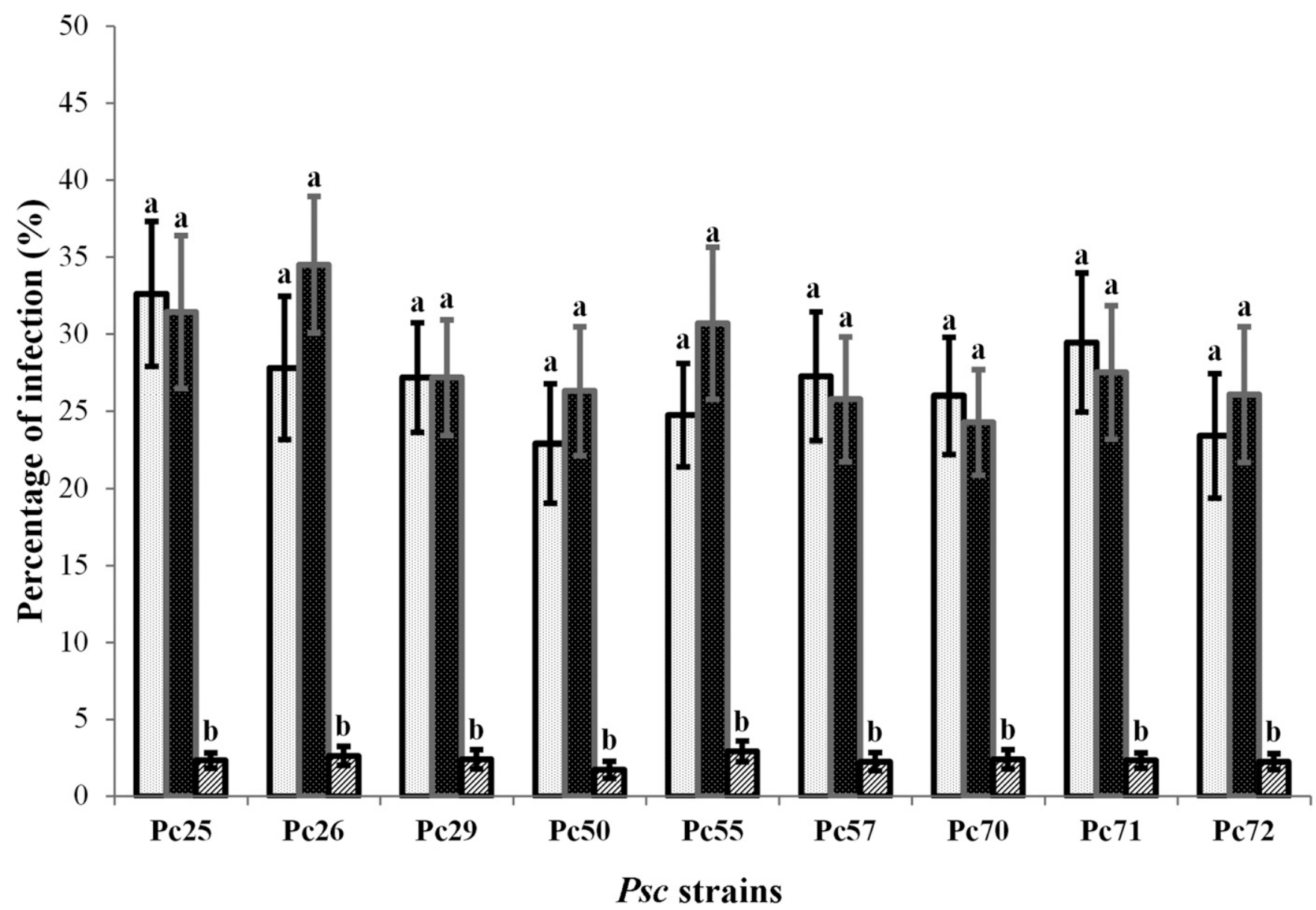

Fig. 4. Disease intensity (mean \pm SE) on parsley, carrot, and parsnip 21 days after inoculations with Pseudomonas syringae pv. coriandricola bacterial strains. Values followed by the same letter in each group of columns and isolates are not significantly different $(P<0.05)$, according to Tukey's honest significant difference test. 
were identified as $P s c$ with similarity from 99.81 to $100 \%$ (query coverage, $98 \%$; expectation value, 0.0 ) compared with data deposited in NCBI and $100 \%$ ( rpoD, gapA, gyrB) when compared with the PAMDB database. The PAMDB BLAST results managed to identify the gltA gene sequences obtained in the present study only to the species level (P. syringae [100\%]) because all of the existing $P s c$ strains previously deposited in PAMDB were amplified using a different gltA primer (Morris et al. 2000), and therefore no data are
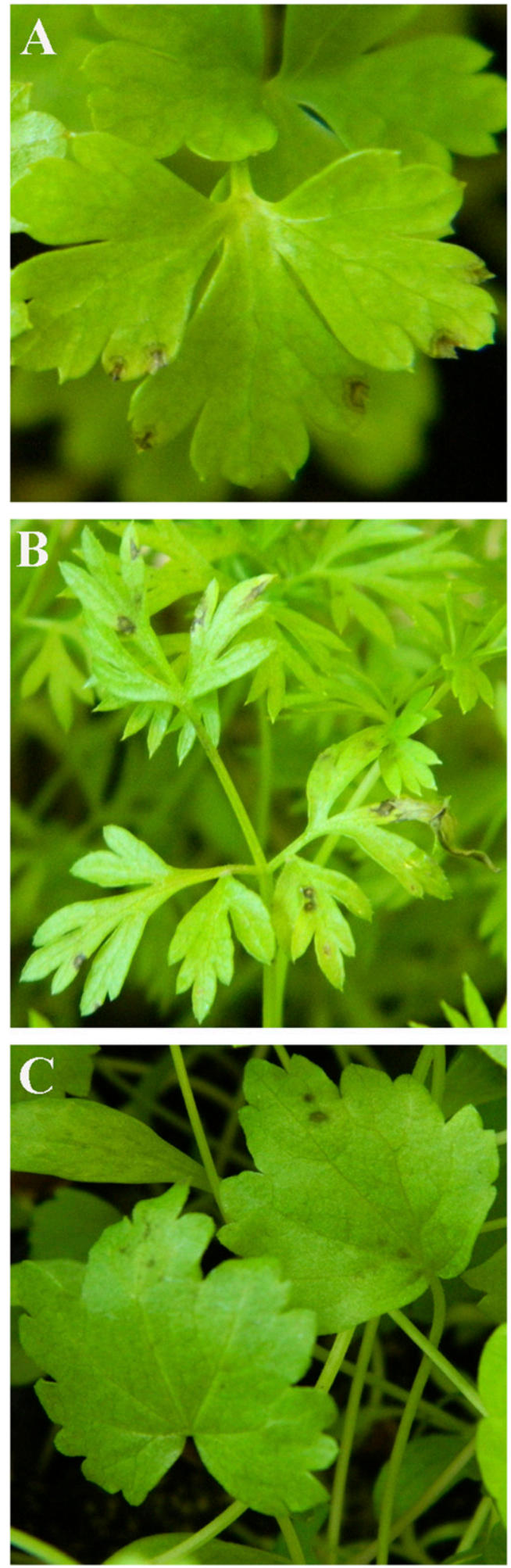

Fig. 5. Leaf spot symptom on inoculated plants of A, parsley, B, carrot, and C, parsnip 21 days after artificial inoculation, using a $10^{8}$ cells/ml suspension. available for comparison with our sequences, which were amplified using the gltA primer proposed by Hwang et al. (2005). Although PAMDB was specially designed for MLST and MLSA of plant pathogens, it contains no data on gltA gene sequencing and is unable to identify tested bacteria on the pathovar level, contrary to the NCBI database, where BLAST results revealed $100 \%$ identity (query coverage, $98 \%$; expectation value, 0.0 ) with the deposited Psc gltA sequences. Based on all of the aforementioned facts, it can be asserted that the existence of a database like PAMDB, specially created for plant pathogenic bacteria, containing not only MLST results but also morphology and pathogenicity data as well, could speed up the search for needed results. It is easier to find data required for MLSA in this database than in NCBI, but it is necessary to constantly enrich it with new data to improve its quality. Bull et al. (2011) tested the ability of MLST to identify Psc causing bacterial spot disease on parsley and emphasized that MLST and phylogenetic analysis based on the concatenate sequences of four housekeeping genes (gap 1, gltA, gyrB, and $r p o D)$ is a powerful diagnostic tool for allocation of $P$. syringae pathovars to a certain genomospecies, also indicating the possibility that $P s c$ could belong to genomospecies 9, together with $P$. cannabina and $P$. cannabina pv. alisalensis. This means that Psc could be a novel pathovar within the species $P$. cannabina, but also stresses the need for further host-range testing before a final conclusion can be reached.

Previous studies reported that $P s c$ causes bacterial leaf spot diseases in members of the family Apiaceae such as parsley, celery, and coriander or cilantro (Bull et al. 2011; Toben and Rudolph 1996). Apart from parsley, carrot and parsnip were also reported in a 2015 study (Popović et al. 2015). In our present study, cross-pathogenicity testing using strains that originated from parsley, carrot, and parsnip did not demonstrate host specificity. After host range testing, Bull et al. (2011) found that Psc strains from parsley and the PSC pathotype strain ICMP 12471 (= CFBP $5010=$ NCPPB 3781) isolated in 1965 from C. sativum var. micocarpur in Germany were also pathogenic on celery (Apium graveolens $\mathrm{L}$.) and coriander or cilantro (C. sativum L.), causing similar leaf spot diseases. Cilantro strains of $P s c$ caused disease on parsley, celery, and cilantro (Koike and Bull 2011). According to Bull et al. (2011), the expanded host range of the pathogen and the potential for reciprocal infections on the original hosts from which they were isolated have epidemiological and practical implications, for example, in the intensive and extensive vegetable industry, where multiple plantings of parsley, celery, or cilantro adjacent to or in rotation with each other can be made throughout a long growing season. Diseased plantings of any of these crops therefore may have significant impacts on adjacent and subsequent plantings. Thus, host-range information is important to farmers and field advisors, who need to take steps to prevent disease and maximize commodity quality (Bull et al. 2011). Some studies reported contrary observations to the effect that Psc strains from coriander (cilantro) produced minor or no symptoms on celery (Cerkauskas 2009; Toben and Rudolph 1996). Moreover, hostrange studies conducted with coriander Psc strains on celery, carrot, fennel, parsley, and parsnip indicated that symptoms did not develop on any of these hosts (Gupta et al. 2013).

Because the pathogen is also seedborne (Bull et al. 2011; Lacy et al. 1996; Taylor and Dudley 1980), it may have been introduced in Serbia by contaminated seeds. In view of the fact that Psc is not restricted to the original host (coriander), which is not grown in Serbia (available official data), we can suppose that the source of infections with Psc is parsley, since there are a few reported records of the disease on it (Bull and Koike 2012; Bull et al. 2011; Koike and Bull 2011; Xu and Miller 2013). It is known that Psc can cross-infect Apiaceae crops under favorable environmental conditions, and it could be possible that the pathogen was splashed onto adjacent carrot and parsnip crops.

The effects of Psc isolates on chlorophyll content, epidermal flavonoids, and total POD activity presented in this work varied depending on the examined host species and Psc strains, which 
suggests a differential plant response to the pathogen. One of the typical disease symptoms, leaf chlorosis (Katagiri et al. 2002), was obtained only in carrot inoculated with isolates that originated from carrot (Pc26) and parsley (Pc72).

As enzymes adapted to a wide spectrum of phenolic substrates, PODs are capable of oxidizing hydroxycinnamic derivates, flavonoids, and other phenolic compounds with different specificities (Bernards et al. 1999). Induction of POD activity during incompatible plant-pathogen interactions is well documented and often correlates with the appearance of new isoforms (Bestwick et al. 1998; Kawano 2003). The increased POD content present in leaves of all examined plant species inoculated with $P s c$ was correlated with accumulation of epidermal flavonoids in leaves inoculated with Pc26 (carrot) and Pc72 (parsley). Phenolic compounds are oxidized to brown compounds (polymerized phenolics) or to more reactive species, quinones, by phenol oxidases and PODs (Takahama and Oniki 2000). The transient decreased epidermal flavonoid content obtained on day 12 after inoculation may be a result of such reactions in the epidermal layer and apoplast. However, we obtained an increase of POD activity by $100 \%$ without induction of new isoforms in symptomatic leaves. Taken together, biochemical analysis of the response to $P S C$ of the three examined species implies that different mechanisms are involved in their interaction with the given plant pathogenic bacteria. The response mechanism involving specific POD reactions in the apoplast and cell wall as the first barrier to $P s c$ in leaves of carrot, parsley, and parsnip will be further analyzed in planned future work.

Table 6. Effect of disease caused by Pseudomonas syringae pv. coriandricola strains on chlorophyll content and epidermal flavonoids in carrot, parsley, and parsnip $^{\mathrm{z}}$

\begin{tabular}{|c|c|c|c|c|c|c|}
\hline \multirow{2}{*}{$\begin{array}{l}\text { Inoculated host and } \\
\text { used strains }\end{array}$} & \multicolumn{2}{|r|}{ Day 3} & \multicolumn{2}{|c|}{ Day 12} & \multicolumn{2}{|r|}{ Day 20} \\
\hline & Chlorophyll & Epidermal flavonoids & Chlorophyll & Epidermal flavonoids & Chlorophyll & Epidermal flavonoids \\
\hline \multicolumn{7}{|l|}{$\overline{\text { Carrot }}$} \\
\hline Negative control & $7.37 \pm 2.52$ & $0.13 \pm 0.04$ & $11.50 \pm 7.54$ & $0.41 \pm 0.09$ & $11.76 \pm 1.93$ & $0.30 \pm 0.05$ \\
\hline Pc55 & $6.95 \pm 1.31$ & $0.16 \pm 0.03$ & $11.37 \pm 0.56$ & $0.23 \pm 0.02$ & $10.13 \pm 1.48$ & $0.32 \pm 0.06$ \\
\hline Pc72 & $4.83 \pm 1.34$ & $0.19 \pm 0.02$ & $8.93 \pm 1.80$ & $0.19 \pm 0.02$ & $9.40 \pm 1.41$ & $0.30 \pm 0.04$ \\
\hline Pc26 & $4.13 \pm 1.88$ & $0.13 \pm 0.01$ & $5.52 \pm 0.86$ & $0.18 \pm 0.03$ & $9.80 \pm 3.52$ & $0.36 \pm 0.07$ \\
\hline \multicolumn{7}{|l|}{ Parsley } \\
\hline Negative control & $10.22 \pm 1.58$ & $0.51 \pm 0.07$ & $11.77 \pm 1.36$ & $0.41 \pm 0.09$ & $16.53 \pm 5.27$ & $0.40 \pm 0.04$ \\
\hline Pc55 & $8.86 \pm 2.18$ & $0.18 \pm 0.02$ & $10.75 \pm 1.71$ & $0.24 \pm 0.02$ & $14.68 \pm 2.09$ & $0.47 \pm 0.07$ \\
\hline Pc72 & $7.52 \pm 0.86$ & $0.16 \pm 0.02$ & 14. $30 \pm 2.82$ & $0.19 \pm 0.02$ & $15.07 \pm 2.91$ & $0.77 \pm 0.06$ \\
\hline Pc26 & $11.47 \pm 1.20$ & $0.18 \pm 0.02$ & $11.28 \pm 1.38$ & $0.18 \pm 0.03$ & $17.02 \pm 3.63$ & $0.58 \pm 0.08$ \\
\hline \multicolumn{7}{|l|}{ Parsnip } \\
\hline Negative control & $8.73 \pm 0.67$ & $0.04 \pm 0.006$ & $11.24 \pm 0.74$ & $0.11 \pm 0.04$ & $11.66 \pm 1.24$ & $0.18 \pm 0.04$ \\
\hline Pc55 & $7.25 \pm 1.12$ & $0.03 \pm 0.008$ & $9.76 \pm 0.86$ & $0.08 \pm 0.01$ & $12.04 \pm 1.10$ & $0.18 \pm 0.03$ \\
\hline Pc72 & $9.61 \pm 0.73$ & $0.04 \pm 0.007$ & $8.98 \pm 1.29$ & $0.08 \pm 0.02$ & $11.80 \pm 1.32$ & $0.47 \pm 0.03$ \\
\hline Pc26 & $9.87 \pm 0.88$ & $0.05 \pm 0.008$ & $9.28 \pm 0.87$ & $0.18 \pm 0.04$ & $12.43 \pm 0.74$ & $0.26 \pm 0.04$ \\
\hline
\end{tabular}

z Values represent means \pm SE.

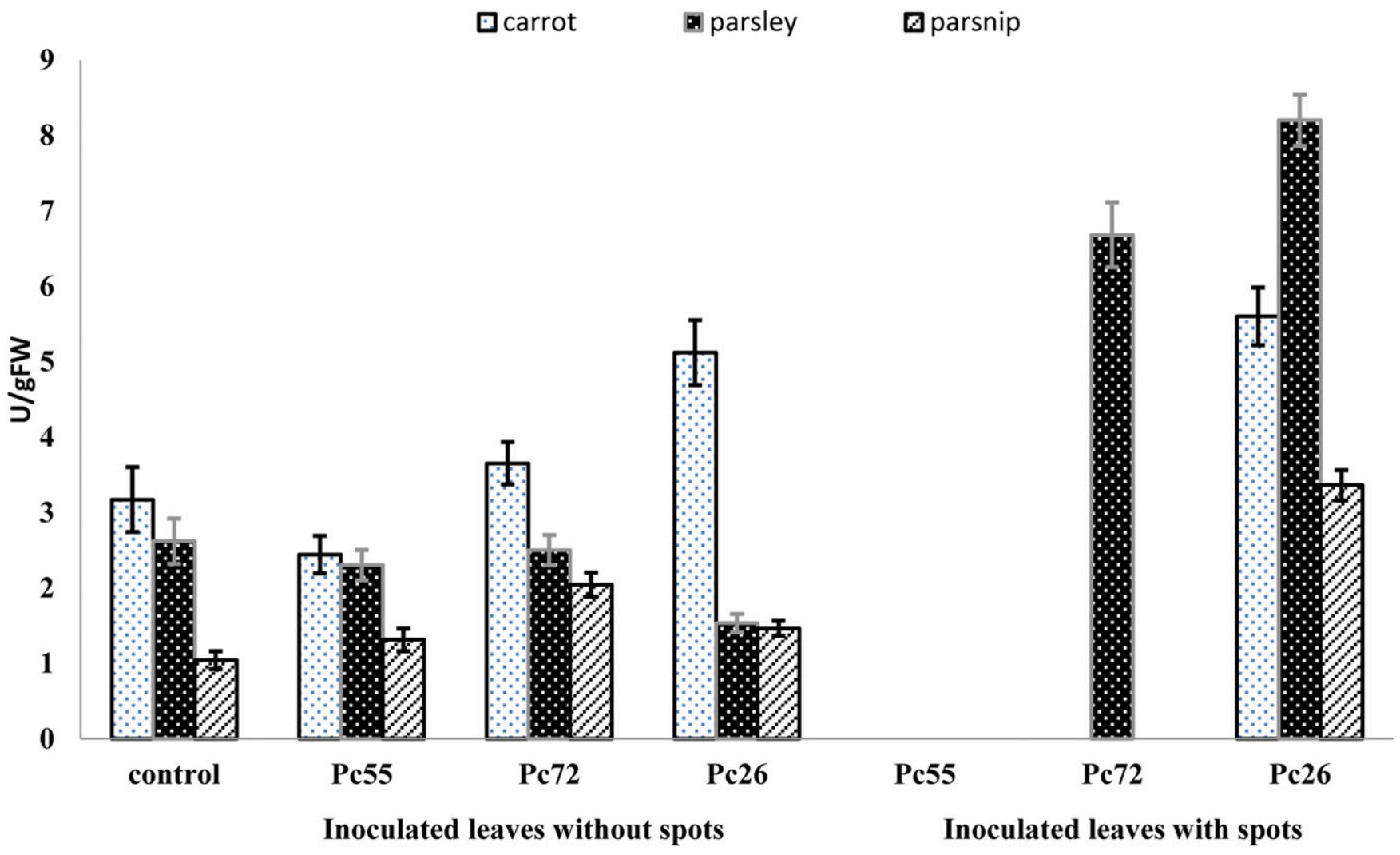

Fig. 6. Changes in the peroxidase activity in leaves of parsley, carrot, and parsnip measured on day 20 after inoculation with strains of Pseudomonas syringae pv. coriandricola. 


\section{Literature Cited}

Bernards, M. A., Fleming, W. D., Llewellyn, D. B., Priefer, R., Yang, X., Sabatino, A., and Plourde, G. L. 1999. Biochemical characterization of the suberizationassociated anionic peroxidase of potato. Plant Physiol. 121:135-146.

Bestwick, C. S., Brown, I. R., and Mansfield, J. W. 1998. Localized changes in peroxidase activity accompany hydrogen peroxide generation during the development of a nonhost hypersensitive reaction in lettuce. Plant Physiol. 118:1067-1078.

Bonomo, M. G., Ricciardi, A., Zotta, T., Parente, E., and Salzano, G. 2008. Molecular and technological characterization of lactic acid bacteria from traditional fermented sausages of Basilicata region (Southern Italy). Meat Sci. 80:1238-1248.

Bozkurt, I. A., Horuz, S., Aysan, Y., and Soylu, S. 2016. First report of bacterial leaf spot of parsley caused by Pseudomonas syringae pv. apii in Turkey. J. Phytopathol. 164:207-211.

Bull, C. T., and Koike, S. T. 2012. Foliar diseases of Apiaceae crops in coastal California. University of California Press-Cooperative Extension, 1-4.

Bull, C. T., Clarke, C. R., Cai, R., Vinatzer, B. A., Jardini, T. M., and Koike, S. T. 2011. Multilocus sequence typing of Pseudomonas syringae sensu lato confirms previously described genomospecies and permits rapid identification of $P$. syringae pv. coriandricola and $P$. syringae pv. apii causing bacterial leaf spot on parsley. Phytopathology 101:847-858.

Cazorla, F. M., Vázquez, M. A., Rosales, J., Arrebola, E., Navarro, J., PérezGarcía, A., and De Vicente, A. 2005. First report of bacterial leaf spot (Pseudomonas syringae pv. coriandricola) of coriander in Spain. J. Phytopathol. 153:181-184.

Cerkauskas, R. F. 2009. Bacterial leaf spot of cilantro (Coriandrum sativum) in Ontario. Can. J. Plant Pathol. 31:16-21.

Cerović, Z. G., Masdoumier, G., Ghozlen, N. B., and Latouche, G. 2012. A new optical leaf-clip meter for simultaneous non-destructive assessment of leaf chlorophyll and epidermal flavonoids. Physiol. Plant. 146:251-260.

Chapman, J. R., Taylor, R. K., Weir, B. S., Romberg, M. K., Vanneste, J. L., Luck, J., and Alexander, B. J. R. 2012. Phylogenetic relationships among global populations of Pseudomonas syringae pv. actinidiae. Phytopathology 102:1034-1044.

Cooksey, D. A., Azad, H. R., and Paulus, A. O. 1991. Leaf spot of cilantro in California caused by a nonfluorescent Pseudomonas syringae. Plant Dis. 75:101.

De Bruijn, F. J. 1992. Use of repetitive (repetitive extragenic palindromic and enterobacterial repetitive intergeneric consensus) sequences and the polymerase chain reaction to fingerprint the genomes of Rhizobium meliloti isolates and other soil bacteria. Appl. Environ. Microbiol. 58:2180-2187.

Dennis, J., and Wilson, J. 1997. Disease Control in Coriander and Other Spice Seeds. RIRDC Research Paper Series No. 97. Rural Industries Research and Development Corporation, Adelaide, Australia.

Dimkić, I., Živković, S., Berić, T., Ivanović, Ž., Gavrilović, V., Stanković, S., and Fira, Đ. 2013. Characterization and evaluation of two Bacillus strains, SS-12.6 and SS-13.1, as potential agents for the control of phytopathogenic bacteria and fungi. Biol. Control 65:312-321.

Elena, K., Alivizatos, A. S., and Varveri, C. 2008. New plant pathogens reported in Greece, 1990-2007. Hell. Plant Prot. J. 1:1-25.

Gardan, L., Shafik, H., Belouin, S., Broch, R., Grimont, F., and Grimont, P. A. D. 1999. DNA relatedness among the pathovars of Pseudomonas syringae and description of Pseudomonas tremae sp. nov. and Pseudomonas cannabina sp. nov. (ex Sutic and Dowson 1959). Int. J. Syst. Evol. Microbiol. 49:469-478.

Gooden, D. J., Ramsey, M., and Hayward, C. 1995. Bacterial blight in coriander. Page 44 in: Proceedings of the 10th Australasian Plant Pathology Society Conference. Australasian Plant Pathology Society, Lincoln University, Christchurch, New Zealand.

Gupta, M., Bharat, N., Chauhan, A., and Vikram, A. 2013. First report of bacterial leaf spot of coriander caused by Pseudomonas syringae pv. coriandricola in India. Plant Dis. 97:418.

Gutiérrez-Barranquero, J. A., Carrión, V. J., Murillo, J., Arrebola, E., Arnold, D. L., Cazorla, F. M., and de Vicente, A. 2013. A Pseudomonas syringae diversity survey reveals a differentiated phylotype of the pathovar syringae associated with the mango host and mangotoxin production. Phytopathology 103:1115-1129.

Horsfall, J. G., and Barratt, R. W. 1945. An improved grading system for measuring plant disease (Abstract). Phytopathology 35:655.

Huey, B., and Hall, J. 1989. Hypervariable DNA fingerprinting in Escherichia coli: Minisatellite probe from bacteriophage M13. J. Bacteriol. 171: 2528-2532.

Hwang, M. S., Morgan, R. L., Sarkar, S. F., Wang, P. W., and Guttman, D. S. 2005. Phylogenetic characterization of virulence and resistance phenotypes of Pseudomonas syringae. Appl. Environ. Microbiol. 71:5182-5191.

Jardini, T. M., Koike, S. T., and Bull, C. T. 2012. First report of bacterial streak of fennel (Foeniculum vulgare) in California caused by Pseudomonas syringae pv. apii. Plant Dis. 96:285.

Katagiri, F., Thilmony, R., and He, S. Y. 2002. The Arabidopsis thaliana-Pseudomonas syringae interaction. Arabidopsis Book 1:e0039.

Kawano, T. 2003. Roles of the reactive oxygen species-generating peroxidase reactions in plant defense and growth induction. Plant Cell Rep. 21: 829-837.
Kimura, M. 1980. A simple method for estimating evolutionary rate of base substitutions through comparative studies of nucleotide sequences. J. Mol. Evol. 16:111-120.

Koike, S., and Bull, C. 2011. Bacterial leaf spot of parsley: Characterization of a new disease. Pages 4-6 in University of California Cooperative Extension Crop Notes. University of California Press, Monterey.

Koike, S. T., and Bishop, A. L. 1990. Bacterial leaf spot of celery caused by Pseudomonas syringae pv. apii in California. Phytopathology 80:890.

Koike, S. T., Little, E. L., Bishop, A. L., and Gilbertson, R. L. 1994. New celery disease appears in California. Calif. Agric. 48:32-34.

Kukavica, B., and Jovanović, S. V. 2004. Senescence-related changes in the antioxidant status of ginkgo and birch leaves during autumn yellowing. Physiol. Plant. 122:321-327.

Kukavica, B. M., Veljović-Jovanović, S., Menckhoff, L., and Lüthje, S. 2012. Cell wallbound cationic and anionic class III isoperoxidases of pea root: Biochemical characterization and function in root growth. J. Exp. Bot. 63:4631-4645.

Kumar, S., Stecher, G., and Tamura, K. 2016. MEGA7: Molecular Evolutionary Genetics Analysis version 7.0 for bigger datasets. Mol. Biol. Evol. 33: $1870-1874$.

Lacy, M. L., Berger, R. D., Gilbertson, R. L., and Little, E. L. 1996. Current challenges in controlling disease of celery. Plant Dis. 80:1084-1091.

Le Marrec, C., Hyronimus, B., Bressollier, P., Verneuil, B., and Urdaci, M. C. 2000. Biochemical and genetic characterization of coagulin, a new antilisterial bacteriocin in the pediocin family of bacteriocins, produced by Bacillus coagulans $\mathrm{I}_{4}$. Appl. Environ. Microbiol. 66:5213-5220.

Lelliott, R. A., and Stead, D. E. 1987. Methods for the Diagnosis of Bacterial Diseases of Plants. Blackwell Scientific Publications, Oxford, UK.

Little, E. L., Bostock, R. M., and Kirkpatrick, B. C. 1998. Genetic characterization of Pseudomonas syringae pv. syringae strains from stone fruits in California. Appl. Environ. Microbiol. 64:3818-3823.

Louws, F. J., Fullbright, D. W., Stephens, C. T., and de Brujin, F. J. 1994. Specific genomic fingerprints of phytopathogenic Xanthomonas and Pseudomonas pathovars and strains generated with repetitive sequences and PCR. Appl. Environ. Microbiol. 60:2286-2295.

Marques, A. S., Marchaison, A., Gardan, L., and Samson, R. 2008. BOX-PCRbased identification of bacterial species belonging to Pseudomonas syringae P. viridiflava group. Genet. Mol. Biol. 31:106-115.

Marques, A. S. A., Corbière, R., Gardan, L., Tourte, C., Manceau, C., Taylor, J. D., and Samson, R. 2000. Multiphasic approach for the identification of the different classification levels of Pseudomonas savastanoi pv. phaseolicola. Eur. J. Plant Pathol. 106:715-734.

Morris, C., Glaux, C., Latour, X., Gardan, L., Samson, R., and Pitrat, M. 2000. The relationship of host range, physiology, and genotype to virulence on Cantaloupe in Pseudomonas syringae from cantaloupe blight epidemics in France. Phytopathology 90:636-646.

Nemeth, J., Paitz, L., and Klement, Z. 1969. The flower stand blight and seed decay of coriander. Acta Phytopathol. Acad. Sci. Hung. 4:57-62.

Pernezny, K., Raid, R. N., and Jones, J. B. 1997. Bacterial leaf spot of cilantro in Florida. Plant Dis. 81:232.

Popović, T., Ivanović, Ž., Ignjatov, M., and Milošević, D. 2015. First report of Pseudomonas syringae pv. coriandricola causing bacterial leaf spot on carrot, parsley and parsnip in Serbia. Plant Dis. 99:416.

Rajashekara, G., Koeuth, T., Nevile, S., Back, A., Nagaraja, K. V., Lupski, J. R., and Kapur, V. 1998. SERE, a widely dispersed bacterial repetitive DNA element. J. Med. Microbiol. 47:489-497.

Redman, C. E., King, E. P., and Brown, I. F., Jr. 1969. Tables for Converting Barratt and Horsfall Rating Scores to Estimated Mean Percentages. Elanco Products, Indianapolis, IN.

Refshauge, S. J., and Nayudu, M. 2001. Invasion by Pseudomonas syringae pv. coriandricola is responsible for bacterial blight of coriander. Plant Sci. 161:621-625.

Refshauge, S. J., Nayudu, M., Vranjic, J., and Bock, C. H. 2010. Infection and dispersal processes of Pseudomonas syringae pv. coriandricola on coriander Phytopathol. Mediterr. 49:42-50.

Sarkar, S. F., and Guttman, D. S. 2004. Evolution of the core genome of Pseudomonas syringae, a highly clonal, endemic plant pathogen. Appl. Environ. Microbiol. 70:1999-2012.

Schaad, N. W., Jones, J. B., and Chun, W. 2001. Laboratory Guide for Identification of Plant Pathogenic Bacteria. American Phytopathological Society, St. Paul, MN.

Takahama, U., and Oniki, T. 2000. Flavonoids and some other phenolics as substrates of peroxidase: Physiological significance of the redox reactions. J. Plant Res. 113:301-309.

Taylor, J. D., and Dudley, C. L. 1980. Bacterial disease of coriander. Plant Pathol. 29:117-121.

Toben, H. M., and Rudolph, K. 1996. Pseudomonas syringae pv. coriandricola, incident of bacterial umbel blight and seed decay of coriander (Coriandrum sativum L.) in Germany. J. Phytopathol. 144:169-178.

Versalovic, J., Schneider, M., De Bruijn, F. J., and Lupski, J. R. 1994. Genomic fingerprinting of bacteria using repetitive sequence-based polymerase chain reaction. Methods Mol. Cell. Biol. 5:25-40.

Xu, X., and Miller, S. A. 2013. First report of bacterial leaf spot of parsley caused by Pseudomonas syringae pv. coriandricola in Ohio. Plant Dis. 97 988 . 